\title{
PENGARUH PENGGUNAAN STRATEGI PEMBELAJARAN PENINGKATAN KEMAMPUAN BERPIKIR (SPPKB)TERHADAP HASIL BELAJAR KEWIRAUSAHAANSISWA KELAS XI SEMESTER GENAP SMK MUHAMMADIYAH 2 METRO T.P 2015/2016
}

\author{
Reisa Farida Amri ${ }^{1}$ Triani Ratnawuri ${ }^{2)}$ \\ Pendidikan Ekonomi FKIP Universitas Muhammadiyah Metro \\ reisafarida@gmail.com ${ }^{1)}$ triani_rw@yahoo.com ${ }^{2)}$
}

\begin{abstract}
Abstrak
Adapun tujuan dalam penelitian ini adalah "Untuk Mengetahui Pengaruh Penggunaan Strategi Pembelajaran Peningkatan Kemampuan Berpikir (SPPKB) Terhadap Hasil Belajar Kewirausahaan Siswa Kelas XI semester genap SMK Muhammadiyah 2 Metro Tahun Pelajaran 2015/2016." Hipotesis dalam penelitian ini adalah "Ada pengaruh yang signifikanStrategi Pembelajaran Peningkatan Kemampuan Berpikir (SPPKB) terhadap hasil belajar kewirausahaan kelas XI semester genap SMK Muhammadiyah 2 Metro Tahun Pelajaran 2015/2016." Subjek dalam penelitian ini adalah siswa kelas XI SMK Muhammadiyah 2 Metro tahun pelajaran 2015/2016. Penelitian ini adalah penelitian eksperimen dengan Penggunakan Strategi Pembelajaran Peningkatan Kemampuan Berpikir (SPPKB) dalam proses pembelajaran kepada peserta didik. Populasi dalam penelitian ini adalah siswa kelas XI SMK Muhammadiyah 2 Metro tahun pelajaran 2015/2016 yang berjumlah 353. Sampel di ambil secara Sampling Purposive dan di peroleh kelas XI TKJ 2 dengan jumlah 32 siswa sebagai kelas yang dijadikan penelitian eksperiman atau sebagai kelas yang mendapat perlakuan Penggunakan Strategi Pembelajaran Peningkatan Kemampuan Berpikir (SPPKB). Dari analisis data hasil penelitian menggunakan rumus regresi linier sederhana didapat t-hitung $=1,24$ sedangkan $\mathrm{t}$-tabel $=1,84$ pada taraf signifikasi 0,05 dengan demikian t-hitung < t-tabel. Ini berarti regresi linier sederhana bersifat nyata, atau hipotesis terima.Dengan demikian dapat disimpulkan bahwa penggunaan strategi pembelajaran peningkatan kemampuan berpikir (SPPKB) dapat meningkatkan hasil belajar kewirausahaan siswa kelas XI SMK Muhammadiyah 2 Metro karena hipotesisnya diterima, yaitu "Ada pengaruh yang signifikanstrategi pembelajaran peningkatan kemampuan berpikir (SPPKB) terhadap hasil belajar kewirausahaan kelas XI semester genap SMK Muhammadiyah 2 Metro Tahun Pelajaran 2015/2016." Dimana siswa yang dinyatakan tuntas belajar dengan $\mathrm{KKM} \geq 70$ setelah diberikan treatment sebanyak 17 siswa atau $53,12 \%$ dan siswa yang dinyatakan belum tuntas sebanyak 15 siswa atau 46,88\%, maka dapat dikatakan proses pembelajaran dikatakan berhasil.
\end{abstract}

Kata kunci : Strategi Pembelajaran Peningkatan Kemampuan Berpikir (SPPKB), Hasil Belajar

\section{PENDAHULUAN}

Pendidikan merupakan salah satu faktor penting dalam perkembangan suatu negara. Kemajuan suatu negara dalam segala hal, baik dalam bidang ekonomi, bidang teknologi, bidang pertanian, maupun bidang-bidang yang lainnya tidak terlepas dari pendidikan untuk memberikan kontribusi yang positif bagi perkembangan sumber daya manusia yang 
berkualitas, karena itu diperlukan pembangunan bangsa khususnya pembangunan di bidang pendidikan.

Pendidikan tidak terlepas dari peran guru. Peran guru disini sangat penting dalam membuka wawasan berpikir yang beragam dari peserta didik sehingga mereka dapat mempelajari konsep dan cara mengaitkan dengan kehidupan nyata sehingga dapat membuka berbagai pintu kesempatan selama hidupnya serta dapat menghasilkan sumber daya manusia (SDM) yang menguasai ilmu pengetahuan dan teknologi (IPTEK)

Perkembangan pendidikan Indonesia yang perlu diperhatikan bahwa pendidikan akan berhasil dengan maksimal manakala setiap elemen dari pendidikan senantiasa memegang teguh tujuan pendidikan nasional. Adapun tujuan pendidikan nasional menurut UU No.22 tahun 2006 disebutkan bahwa:

"Tujuan pendidikan nasional berfungsi mengembangkan kemampuan dan membentuk watak serta peradaban bangsa yang bermartabat dalam rangka mencerdaskan kehidupan bangsa. bertujuan untuk berkembangnya potensi peserta didik agar menjadi manusia yang beriman dan bertakwa kepada Tuhan Yang Maha Esa, berakhlak mulia, sehat, berilmu, cakap, kreatif, mandiri dan menjadi warga negara yang demokratis serta bertanggung jawab."

Untuk mencapai tujuan pendidikan yang mulia ini maka disusunlah kurikulum yang merupakan seperangkat rencana dan peraturan mengenai tujuan, isi, bahan dan metode pembelajaran. Hal ini dilaksanakan salah satunya agar meningkatkan mutu pendidikan nasional.

Guru sebagai tenaga pendidikan harus dapat mengembangkan potensi siswa secara optimal dengan kemampuan untuk berkreasi ,mandiri, bertanggung jawab dan dapat memecahkan masalah-masalah yang dihadapi dan dimiliki karakter yang baik sehingga nantinya dapat melaksanakan fungsinya sebagai warga negara dalam memberdayaan siswa secara optimal maka tidak terlepas dari pembelajaran yang sesuai dengan karakteristik siswa itu sendiri.

Proses pembelajaran yang terjadi didalam kelas sebaiknya tidak hanya didominasi oleh guru saja, akan tetapi harus siswa yang lebih aktif karena memang siswa yang belajar, dan guru berperan sebagai pendamping dan pengontrol, sehingga siswa tidak lagi sebagai objek belajar tetapi sebagai subjek belajar, jadi jelaslah bahwa memang siswa yang harus berperan aktif dalam proses pembelajaran untuk mendapatkan dan mengembangkan pengetahuan itu sementara peran guru bukan sebagai satusatunya sumber belajar akan tetapi sebagai mediator dan fasilitator dalam rangka membantu optimalisasi belajar siswa. 
Strategi Pembelajaran Peningkatan Kemampuan Berpikir (SPPKB) merupakan strategi pembelajaran yang bertumpu kepada pengembangan kemampuan berpikir siswa melalui telaah fakta-fakta atau pengalaman anak sebagai bahan untuk memecahkan masalah yang diajukan. selain itu dengan menggunakan strategi pembelajaran ini siswa akan lebih aktif dalam proses pembelajaran karena Strategi Pembelajaran Peningkatan Kemampuan Berpikir (SPPKB) menekankan kepada keterlibatan siswa secara penuh dalam belajar. Hal ini sesuai dengan Hakikat SPPKB yang tidak mengharapkan siswa sebagai objek belajar yang hanya duduk mendengarkan penjelasan guru kemudian mencatat untuk dihafalkan. Berdasarkan permasalahan tersebut di atas, rumusan masalah dalam penelitian ini adalah: "Apakah Terdapat Pengaruh Penggunaan Strategi Pembelajaran Peningkatan Kemampuan Berpikir (SPPKB) Terhadap Hasil Belajar Siswa Kelas XI semester genap SMK Muhammadiyah 2 Metro Tahun Pelajaran 2015/2016".

\section{KAJIAN PUSTAKA}

\section{Hasil Belajar}

Belajar pada hakekatnya merupakan aktifitas yang utama dalam serangkaian proses pendidikan di sekolah. Hal inidapat dipahami karna berhasil atau tidaknya tujuan pendidikan adalah dominan tergantung pada bagaimana proses belajar mengajar itu berlangsung. Oleh karna itu proses belajar selalu menjadi sorotan utama khususnya bagi para ahli pendidikan.

Menurut Suparno dalam bukunya Sardiman (2010:38) Hasil belajar merupakan hasil yang dipengaruhi oleh pengalaman subjek belajar dengan dunia fisik dan lingkungannya, hasil belajar seseorang tergantung pada apa yang telah diketahui, sisubjek belajar, tujuan, motivasi yang memengaruhi proses interaksi dengan bahan yang sedang dipelajari.

Dimiyati dan Mujiono (2006:3) menyatakan bahwa Hasil belajar merupakan hasil dari suatu interaksi tindak belajar dan tindak mengajar pada akhir proses belajar. Hasil belajar dapat dibagi menjadi dua yaitu dampak pengajaran dan dampak pengiring. Dampak pengajaran adalah hasil yang dapat diukur seperti yang tertuang dalam rapor angka dalam ijazah, atau kemampuan meloncat setelah latihan. Dampak pengiring adalah terapan pengetahuan dan kemampuan dibidang lain, suatu transfer belajar.

Hasil belajar tampak sebagai terjadinya perubahan tingkah laku pada diri siswa, yang dapat diamati dan diukur 
dalam bentuk perubahan pengetahuan, sikap dan keterampilan. Perubahan tersebut dapat diartikan terjadinya peningkatan dan pengembangan yang lebih baik dibandingkan dengan sebelumnya, misalnya dari tidak tahu menjadi tahu, sikap kurang sopan menjadi sopan, dan sebagainya.

Berdasarkan definisi tersebut diatas ternyata bahwa hasil belajar itu bukan sekedar merupakan sejumlah pengetahuan yang diperolah siswa saja, melainkan juga mencakup adanya perubahan perilaku, dan perubahan sikap pada diri siswa. Jadi, hasil belajar itu merupakan perubahan yang meliputi 3 aspek yaitu: (1) Perubahan pengetahuan (kognitif), (2) Perubahan sikap (afektif), dan (3) Perubahan keterampilan (psikomotorik).

Berdasarkan beberapa pendapat di atas, dapat disimpulkan bahwa yang dimaksud dengan hasil belajar adalah hasil yang diperoleh dari peserta didik dalam mengikuti proses pembelajaran Prakarya Dan Kewirausahaan yang diberikan oleh guru dan disajikan dalam bentukangkaangka pada buku nilai semester genap Tahun Pelajaran 2015/2016.

\section{Strategi Pembelajaran}

Strategi Pembelajaran merupakan rencana tindakan (rangkaian kegiatan) termasuk penggunaan metode dan pemanfaatan berbagai sumber atau kekuatan dalam pembelajaran yang disusun untuk mencapai tujuan tertentu. Strategi pembelajaran didalamnya mencakup pendekatan, model, metode dan teknik pembelajaran secara spesifik.

$$
\text { Menurut Uno (2008:45) "Strategi }
$$

Pembelajaran merupakan hal yang perlu di perhatikan guru dalam proses pembelajaran." Sedangkan Menurut Dick dan Carey (Sanjaya 2009:7):

"Strategi Pembelajaran adalah komponen-komponen dari materi termasuk aktivitas sebelum pembelajaran, dan partisipasi peserta didik yang merupakan prosedur pembelajaran yang digunakan untuk kegiatan selanjutnya."

Berdasarkan uraian di atas, dapat disimpulkan bahwa strategi pembelajaran merupakan perpaduan dari urutan kegiatan dan cara pengorganisasian materi pelajaran, siswa, peralatan, bahan, dan waktu yang digunakan dalam proses pembelajaran untuk mencapai tujuan yang telah ditentukan.

Menurut Uno (2008 : 3) Strategi Pembelajaran adalah :

"Cara-Cara yang akan digunakan oleh pengajar untuk memilih kegiatan belajar yang akan digunakan oleh pengajar untuk memilih kegiatan belajar yang akan digunakan selama proses pembelajaran."

Berdasarkan pendapat di atas, dapat disimpulkan bahwa strategi pembelajaran merupakan cara-cara yang akan dipilih dan digunakan oleh seorang pengajar untuk 
sehingga akan memudahkan peserta didik menerima dan memahami materi pembelajaran yang pada akhirnya tujuan pembelajaran dapat dikuasai diakhir kegiatan belajar.

\section{Strategi Pembelajaran Peningkatan Kemampuan Berpikir (SPPKB)}

Strategi Pembelajaran Peningkatan Kemampuan Berpikir (SPPKB) merupakan strategi pembelajaran yang bertumpu kepada pengembangan kemampuan berpikir siswa melalui telaah fakta-fakta atau pengalaman anak sebagai bahan untuk memecahkan masalah yang diajukan. Dalam SPPKB, materi pelajaran tidak disajikan begitu saja kepada peserta didik. Akan tetapi, peserta didik dibimbing untuk menemukan sendiri melalui proses dialog dengan memanfaatkan pengalaman peserta didik.

Menurut Sanjaya, (2009:117-228):

"Strategi pembelajaran peningkatan kemampuan berpikir (SPPKB) merupakan suatu strategi pembelajaran yang bertumpu pada proses peningkatan kemampuan berpikir siswa melalui proses telaah fakta-fakta, dan menghubungkan antara pengalaman yang dialami siwa dan dikaitkan dengan kehidupan nyata."

Sedangkan Menurut Peter Reason (Sanjaya, 2009:230) :

"Berpikir (thinking) adalah proses mental seorang yang lebih dari sekadar mengingat (remembering) dan memahami (comprehending). Menurut Reason mengingat dan memahami lebih bersifat pasif daripada kegiatanberpikir (thinking). Pendapat tersebut juga didukung oleh pernyataan Gunawan (2012:186) bahwa "Suatu proses pendidikan akan lebih bermakna bagi peserta didik, karena menekankan kepada peserta didik untuk lebih banyak beraktifitas, mereka akan mendapatkan pengetahuan dengan sendirinya, mereka belajar "mengalami" bukan menghapal fakta dan konsep, yang akan lebih membangkitkan minat dan gairah mereka dalam belajar".

Berdasarkan Pendapat yang dikemukakan diatas, maka SPPKB menghendaki siswa harus aktif dalam proses pembelajaran, tidak hanya sekedar mendengar dan mencatat apa yang diberikan oleh guru, selain itu siswa juga harus mampu dalam mengkontruksi dan membangun pengetahuan baru. Artinya, bahwa SPPKB menekankan kepada keterlibatan dan keaktifan siswa secara penuh dalam pembelajaran.

Tahapan-tahapan Pembelajaran SPKB, Menurut Sanjaya (2009:232), menjelaskan bahwa Strategi Pembelajaran Peningkatan Kemampuan Berpikir (SPPKB) memiliki enam tahapan, antara lain:

1) Tahap Orientasi

2) Tahap Pelacakan 
3) Tahap Konfrontasi

4) Tahap Inkuiri

5) Tahap Akomodasi

6) Tahap Transfer

Sebagai strategi pembelajaran yang diarahkan untuk mengembangkan kemampuan berpikir, SPPKB pada dasarnya memiliki tiga karakteristik utama, yaitu sebagai berikut:

1) Proses pembelajaran melalui SPPKB menekankan kepada proses kekuatan mental siswa secara maksimal. SPPKB bukan model pembelajaran yang membiarkan siswa untuk pasip atau sekedar mendengar dan mencatatapa yang disampaikan oleh guru, tetapi menginginkan agar siswa aktif dalam aktivitas proses berpikir. Setiap kegiatan belajar yang berlangsungd isebabkan dorongan mental yang diatur oleh otak. Karena Pembelajaran disini adalah peristiwa mental bukan peristiwa behavioral yang lebih menekankan aktivitas fisik.

2) SPPKB dilaksanakan dalam situasi dialogis dan proses Tanya jawab secaraterus- menerus. Proses pembelajaran melalui dialog dan Tanya jawab itu diarahkan untuk mengembangkan daya piker siswa akan masalah yang diajukan, sehingga siswa menjadi memiliki pandangan tersendiri atas solusi atau cara pemecahan masalah yang telah diberikan, yang pada gilirannya kemampuan berpikir itu dapat membantu siswa untuk memperoleh pengetahuan yang mereka konstruks sendiri.

3) SPPKB menyandarkan akan dua masalah pokok, yaitu sisi proses dan hasil belajar. Proses belajar diarahkan untuk meningkatkan kemampuan berpikir, sedangkan sisi hasil belajar diarahkan untuk mengkonstruksi pengetahuan atau penguasaan materi pembelajaran baru.

\section{METODE PENELITIAN}

Rancangan penelitian dapat diartikan sebagai strategi mengatur latar (setting) penelitian agar penelitian memperoleh data yang tepat (valid) sesuai dengan karakteristik variabel dan tujuan penelitian. Dalam penelitian ini jenis penelitian yang dilakukan adalah penelitian yang bersifat pengaruh, yang mengkaji pengaruh antara variabel bebas dan terikat, penelitian ini mencari bagaimana pengaruh penggunaan Strategi pembelajaran Peningkatan Kemampuan Berpikir (SPPKB) terhadap hasil belajar Kewirausahaan, Metode Experimen Quasi Experimental Design jenis Control Group Pre-Test Post-Testdalam desain ini terdapat kelas eksperimen dan kelas 
kontrol yang akan peneliti lihat perbedaan pencapaian antara kedua kelas tersebut. Dalam penelitian ini yang menjadi kelas eksperimen adalah kelas XI TKJ 2 dan yang menjadi kelas kontrol adalah kelas XI TKJ 1.

Teknik sampling yang digunakan dalam ini adalah sampling purposive. Menurut Sugiyono (2008:218) purposive sampling adalah tehnik pengambilan sampel sumber data dengan pertimbangan tertentu yakni sumber data dianggap paling tahu tentang apa yang diharapkan. Berdasarkan teknik sampling tersebut, maka dalam penelitian ini yang menjadi sampel yaitu kelas XII TKJ 2 yang terdiri dari 32 siswa yang memiliki masalah hasil belajar paling rendah.Maka Sampel yang diambil dalam penelitian ini adalah Kelas XI TKJ 1 sebagai kelas Eksperimen, dan Kelas XI TKJ 2 sebagai kelas kontrol.

Pengumpulan data dalam penelitian selalu memerlukan data yang tepat dan akurat sehingga kegiatan penelitian yang dilakukan berhasil mengumpulkan data yang dapat dipertanggung jawabkan, maka ditempuh dengan menggunakan metode sebagai berikut observasi, wawancara, dokumentasi dan test. Data utama dalam penelitian ini menggunakan instrumen test.

Sebelum analisis data dilakukan, instrumen diuji yaitu uji perysaratan instrumen validitas dan reliabilitas. Uji validitas menggunakan rumus korelasi Pearson Product Moment dan uji reliabilitas menggunakan KR-20.

Teknik analisis data dalam penelitian ini digunakan uji normalitas, uji homogenitas, dan uji hipotesis. Uji hipotesis menggunakan uji regresi linier dan uji signifikansi menggunakan uji F.

\section{PEMBASAHAN HASIL PENELITIAN}

Berdasarkan hasil penelitian dapat diketahui bahwa pada tahap evaluasi uji pre-test, bahwa siswa yang mencapai tuntas belajar hanya 28,12\% (9 siswa), sedangkan siswa yang belum mencapai tuntas belajar adalah 71,88\% (23 siswa). Dengan demikian dapat ditemukan bahwa jumlah siswa yang belum tuntas belajar atau belum mencapai standar ketuntasan yang telah ditetapkan masih banyak yaitu $71,88 \%$ atau 23 siswa dari total keseluruhan siswa sebanyak 32 siswa. Pada tahap evaluasi post-test, setelah siswa mendapatkan treatment atau perlakuan dengan menggunakan strategi pembelajaran peningkatan kemampuan berpikir (SPPKB) yang mencapai tuntas belajar berjumlah 53,12 (17 siswa), sedangkan siswa yang belum mencapai tuntas belajar berjumlah 46,88 (15 siswa), dari total keseluruhan siswa sebanyak 32 siswa. 
Dalam penelitian ini setelah siswa mendapatkan treatment atau perlakuan dengan menggunakan strategi pembelajaran peningkatan kemampuan berpikir (SPPKB) hasil belajar kewirausahaan mengalami peningkatan dilihat dari perbandingan pada evaluasi pre-test dan evaluasi post-test, yaitu siswa yang mencapai kriteria ketuntasan minimal pada evaluasi pre-test adalah $28,12 \%$ atau 9 siswa dari total keseluruhan siswa sebanyak 32 siswa, sedangkan siswa yang mencapai kriteria ketuntasan minimal pada evaluasi post-test adalah 53,12\% atau 17 siswa, dari total keseluruhan siswa sebanyak 32 siswa.

Berdasarkan perhitungan uji hipotesis, didapatkan bahwa Ho diterima. Maka ada pengaruh yang signifikan penggunaan strategi pembelajaran peningkatan kemampuan berpikir (SPPKB) terhadap hasil belajar kewirausahaan siswa kelas XI semester genap SMK Muhammadiyah 2 Metro.

\section{KESIMPULAN DAN SARAN}

Berdasarkan penelitian yang dilakukan oleh penulis dapat disimpulkan bahwa hasil pengumpulan data dalam penelitian dari 32 siswa yang diberikan perlakuan (treatment) dengan menggunakan strategi pembelajaran peningkatan kemampuan berpikir
(SPPKB), siswa yang hasil belajar kewirausahaan termasuk dalam kategori tuntas sebanyak 17 siswa atau sebesar $53,12 \%$, sedangkan siswa yang hasil belajar kewirausahaan termasuk dalam kategori belum tuntas sebanyak 15 siswa atau sebesar $46,88 \%$.

Pada pengujian dengan menggunakan rumus Regresi Linier Sederhana diperoleh $\alpha=50,0970 \mathrm{~b}=0,3160$ sehingga dengan demikian $\hat{Y}=\alpha+b X$, adalah $Y=50,0970$ $+0,3160 X$, kemudian dari hasil analisis yang dilakukan maka terbukti bahwa ada pengaruh yang positif penggunaan strategi pembelajaran peningkatan kemampuan berpikir (SPPKB) terhadap hasil belajar kewirausahaan pada siswa SMK Muhammadiyah 2 Metro. Hal ini dibuktikan dengan perhitungan analisis data dapat diketahui bahwa nilai tersebut $\mathrm{F}_{\text {hitung }}<\mathrm{F}_{\text {tabel, }}$ dan terlihat bahwa pada taraf signifikan $5 \%$ yaitu 1,18 < 1,84 yang dapat dilihat pada tabel daftar distribusi F. Dengan demikian maka hipotesis diterima. Sehingga ada pengaruh yang signifikan penggunaan strategi pembelajaran peningkatan kemampuan berpikir (SPPKB) terhadap hasil belajar kewirausahaan siswa kelas XI SMK Muhammadiyah 2 Metro.

Berdasarkan kesimpulan yang diperoleh selama melaksanakan penelitian dan hasil pengamatan dalam pelaksanaan 
penelitian, maka penulis mencoba mengemukakan saran sebagai berikut :

1. Di dalam proses pembelajaran agar hasil belajar mengalami peningkatan, guru sebagai motivator diharapkan dapat melaksanakan tugasnya dengan baik dan dapat mengajak siswa agar aktif dalam proses pembelajaran serta dapat memotivasi siswa untuk belajar lebih giat, aktif dan kondusif. Hal ini dapat diatasi dengan penggunaan model pembelajaran yang tepat. Salah satunya dengan strategi pembelajaran peningkatan kemampuan berpikir (SPPKB).

2. Strategi Pembelajaran Peningkatan Kemampuan Berpikir (SPPKB) menghendaki siswa harus aktif dalam proses pembelajaran, tidak hanya sekedar mendengar dan mencatat apa yang diberikan oleh guru, selain itu siswa juga harus mampu dalam mengkontruksi dan membangun pengetahuan baru. Artinya, bahwa strategi Pembelajaran Peningkatan Kemampuan Berpikir (SPPKB) menekankan kepada keterlibatan dan keaktifan siswa secara penuh dalam pembelajaran.

\section{DAFTAR PUSTAKA}

Dimyati, Mudjiono. 2006. Belajar dan Pembelajaran Indonesia.
Departemen Pendidikan dan

Kebudayaan Pusat Perbukuan. Rineka Cipta.

Gunawan, Heri. 2012. Pendidikan karakter konsep dan Implementasi. Bandung. Alfabeta.

Sanjaya, Wina. 2009. Strategi Pembelajaran Berorientasi Standar Proses Pendidikan. Jakarta.kencana

Sardiman. 2010. Interaksi dan Motivasi Mengajar. Jakarta. Rajawali Press.

Sugiyono, 2008. Metode Penelitian Kuantitatif, Kualitatif, dan $R \& D$. Bandung Alfabeta.

Universitas Muhammadiyah Metro.2015. Pedoman Penulisan Karya Ilmiah edisi revisi 3.Um metro.

Uno, Hamzah B .2008. Model Pembelajaran. Jakarta: Bumi Aksara.

UU No.22 .2006. Tujuan Pendidikan Nasional. Jakarta: Menteri Pendidikan Nasional, 
